\title{
Fostering Human Capital Development Through the Triple Helix Model of Innovation: Cases from Selected Local Colleges and Universities (LCUs) in Metro Manila
}

\author{
Juvy B. Hermosura \\ University of Makati (email: juvy.hermosura@umak.edu.ph)
}

\begin{abstract}
This study attempts to provide a modest contribution in the field of public administration by giving emphasis on human capital development which can be made possible through industry-academe-government collaboration otherwise known as the triple helix model of innovation. This model shows the dynamics arising from the interactions between the three principal institutional spheres in an economy - academe, government, and industry. The study examines the various partnership initiatives of identified Local Colleges and Universities (LCUs) in Metro Manila aimed at producing better quality graduates who can contribute to economic development. Using desk study and Key Informants Interview (KII) in gathering data, it was found out that LCUs are already into various engagements with the industry though still very limited as the usual partnership modes cited are on internship, scholarship, physical resources sharing, and faculty training. There are only few programs jointly designed by the university and industry with government participation but can be a good benchmark for other LCUs and local government units. The study draws the following suggestions for policy consideration: to promote triple helix model of innovation in human capital development programs; flexibility to design courses relevant to the community; government incentives for companies collaborating with universities; institutionalization of industry practitioners involvement in curriculum development; provision of timely and usable labor market data; and creation of LCUs particularly in the provinces and capacitating them using the triple helix model.
\end{abstract}

\section{Keywords:}

collaboration; higher education; quality graduates

\section{Introduction}

Developing a country's human capital is crucial to achieving sustainable economic growth and development. As such, investing in tertiary education is beneficial to both individual and society. To the individual, higher education boosts productivity. To the society, productive workforce drives economic growth and contributes to government 
revenues. Also, a more specialized human capital propels research and development essential for the expansion of a country's knowledge frontier (PBEd, 2015).

The Philippine Development Plan, 2017-2022, published by the National Economic and Development Authority of the Philippines enumerates the country's aspirations for the next five years envisioning the Philippines to become an upper-middle income country by 2022 based on more inclusive economic growth that will reduce inequalities and poverty particularly in rural areas. Human capital development through education is key to this strategy.

Addressing the issues on access and equity in higher education is the creation of Local Colleges and Universities (LCUs) as an effect of the passage of RA 7160 also known as the Local Government Code of 1991. It is a Local Government Unit's (LGU) response to poor people's inability to access higher education. The global trend towards mass higher education and the inability of the national government to provide the necessary funds to support the aspirations of all college bound students nationwide, and the autonomy granted them by the Local Government Code embolden LGUs to establish LCUs that offer courses based on the surveyed needs of their constituents, rethink what courses will yield more jobs, and strategically plan with human resources available in their respective communities on how educational services could be best delivered to the community (Danao, 2005). The creation of LCUs is a poverty intervention program which brings hope to millions of Filipinos aspiring to earn a degree and soon land a job that will unleash them from the bondage of poverty. Thus, the establishment of LCUs is an LGU's investment in human capital development (Pernia, 2017).

Participation in higher education has expanded strongly in recent years with the total number of students enrolled in tertiary education grew from 2.2 million in 1999 to 4.1 million in 2015/16 according to World Education News and Reviews (WENR). Furthermore, the Universal Access to Quality Tertiary Education Act signed by Pres. Duterte in 2017 making education in state universities and colleges tuition-free may help boost enrolment. While the government seeks to expand access and participation, it is even more important to improve the quality of education.

Human capital basically means productive members of the society - skilled workforce, entrepreneurs, and the like. However, the Philippine Statistics Authority data on 
unemployment rate for January, 2019 shows that 20.9 percent of the unemployed are college graduates. Ideally, graduation should translate to employment. According to UNESCO Graduate Employability in Asia report, employers want students to be trained according to the needs of the workplace and want to do away with subjects irrelevant to the needs of the working world. A study of the People Management Association of the Philippines (PMAP) showed that hindrances to employment include lack of critical thinking, initiative, and effective communication skills. This was supported by another study conducted by Jobstreet.com in February 2018 among 503 employers saying that employers show a shift in hiring preferences from experience-based qualifications to interpersonal and $21^{\text {st }}$ century skills (attitude/work ethic, communication skills, and analytical thinking). Looming ahead are more challenges brought by the fourth industrial revolution which could make jobhunting tougher. According to Asian Development Bank (ADB), industry is rapidly changing as over 48 percent of job functions are now at risk for automation within the next few years thereby expanding the ranks of those who could find themselves jobless.

The academe, industry, and government should work together to develop the knowledge and skills of the people so they can contribute productively towards nation building. It is in this light that this study is built on the triple helix model of innovation to show the dynamics arising from the interaction between the three primary institutional spheres in an economy: the academe, industry, and government. It seeks to find out the initiatives done by the Local Colleges and Universities (LCUs) in terms of linkages and partnerships; how these linkage programs address the constraints and issues towards producing better quality graduates; and come up with policy recommendations institutionalizing academe-industry-government collaboration. Inspired by the asset-based community development theory and inclusive growth, it is believed that LCUs, which depend solely from their respective local government units for funding, need to be empowered through the assistance of the private sector on various partnership modalities and provision of a conducive policy environment by the government for improved productivity and competitiveness.

\section{Higher Education in the Philippines: Highlights and Lowlights}

The number of higher education institutions (HEIs) in the Philippines is ten times more than its neighboring countries according to the Global Competitiveness Index Report 
2019. Similarly, the gross tertiary enrollment rate increased from 27.5 percent in 2005 to 35.7 percent in 2014, while the total number of students enrolled in tertiary education grew from 2.2 million in 1999 to 4.1 million in 2015/16. A continuous increase in tertiary enrollment is expected to happen with the signing of the Universal Access to Quality Education Act by President Duterte making education in State Colleges and Universities (SUCs) and qualified Local Colleges and Universities (LUCs) tuition-free. These are clear manifestations of the government's effort to expand participation and access to higher education as well as addressing quality issue. However, the Philippine National Development Plan noted that "the Philippines' lackluster performance in producing innovators..., researchers (81 researchers per million population versus 205 in Indonesia and 115 in Vietnam), and knowledge producers (28 out of 777 journals or 3.6 percent are listed under Thomson Reuters, Scopus, or both) indicates that the country has lagged behind many of its ASEAN neighbors in producing the researchers, innovators, and solutions providers needed to effectively function in a knowledge economy" (WENR).

\section{Table 1.}

Undergrad Student Enrolment by Type of Higher Education Institution, 2013-2017

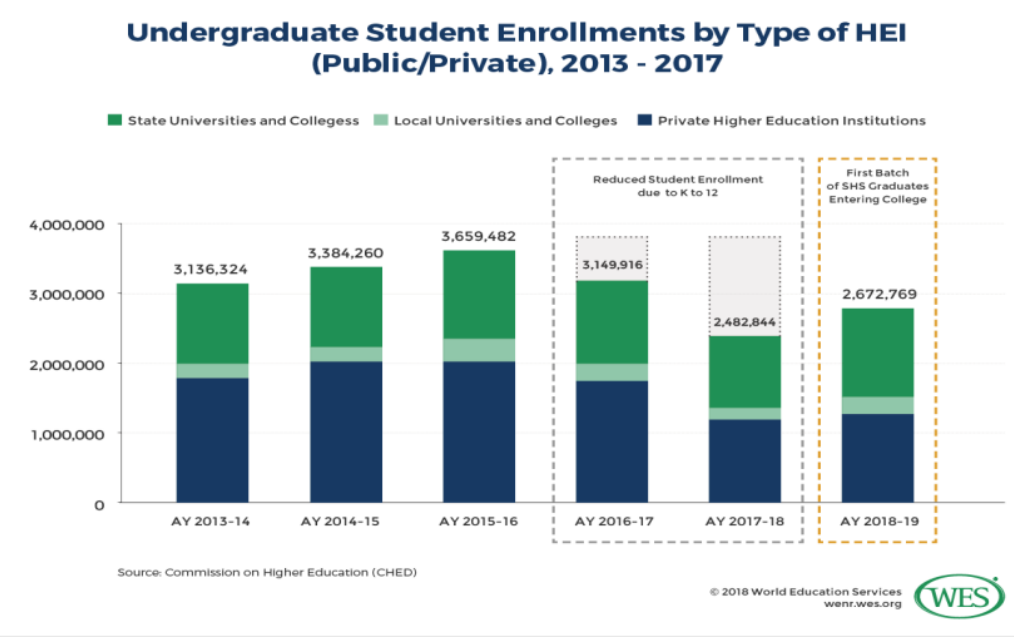

Source: Obtained from JobsFit 2022

Commission on Higher Education (CHED) data shows that the number of HEIs in the Philippines has grown rapidly over the past decades registering an increase of 1,943 from 1,776 between 2007 and 2016/17 alone making the Philippines the country with the highest number of HEIs in Southeast Asia. The three types of public tertiary education institutions in the Philippines as classified by CHED are: 
- State Universities and Colleges or SUCs are public institutions "with independent governing boards and individual charters established by and financed and maintained by the national government". In order to be classified as a university, institutions need to offer graduate programs in addition to a minimum number of bachelor programs in a range of disciplines. There are presently 112 SUCs in the Philippines.

- Local Colleges and Universities (LCUs) are public institutions established and funded by local government units. There are presently 107 local universities and colleges.

- Other government schools form a category that comprises specialized HEIs that provide training related to public services, such as the Philippine National Police Academy or the Philippine Military Academy, for example. There are presently 14 of these institutions.

Majority (88 percent) of HEIs in the Philippines are privately owned. There were 1,710 private HEIs in operation in the 2016/17 academic year, which include both religiously affiliated institutions (mostly Catholic schools) and non-sectarian institutions. Most of these institutions offer the same type of tertiary education programs as public institutions and are overseen by CHED.

Table 2.

Higher Education in the Philippines in 2016/2017

\begin{tabular}{|c|c|c|}
\hline \multicolumn{3}{|c|}{ Higher Education Institutions in the Philippines in 2016 / 2017} \\
\hline TYPE OF INSTITUTION & NUMBER* & PERCENT OF TOTAL \\
\hline Public & 233 & $12 \%$ \\
\hline State Universities and Colleges & 112 & - \\
\hline Local Colleges and Universities & 107 & - \\
\hline Other Government School & 14 & - \\
\hline Private & 1,710 & $88 \%$ \\
\hline Total & 1,943 & $100 \%$ \\
\hline $\begin{array}{l}\text { Source: Commission on Higher Educatic } \\
\text { "Numbers do not include satellite camp }\end{array}$ & & $\begin{array}{r}\text { Id Education Services } \\
\text { wenr.wes.org }\end{array}$ \\
\hline
\end{tabular}

Source: Obtained from JobsFit 2022

Enrollment in public institutions remains substantial, considering the large number of private HEIs. While the share of private sector enrollments in the Philippines is high by international standards, 45.8 percent of the country's 3.5 million tertiary students were 
enrolled in public institutions in the 2016/17 academic year; 39 percent of students studied at state universities and colleges, 6.2 percent at local universities and colleges, and a small minority of 0.17 percent at other government schools. The largest public university in the Philippines is presently the Polytechnic University of the Philippines, which maintains branch campuses throughout the country.

Table 3.

Student Enrolment in Higher Education Institutions in the Philippines for 2016/2017

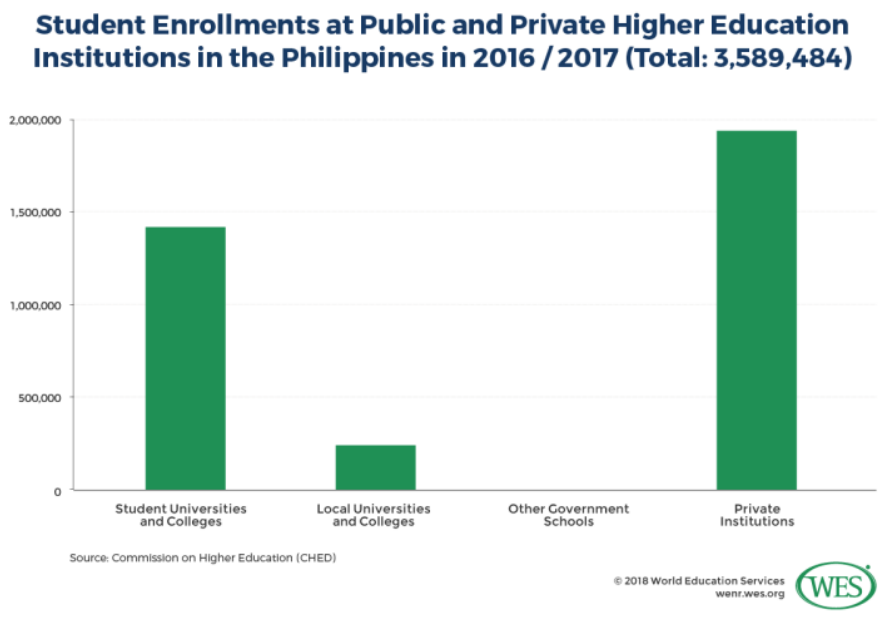

Source: JobsFit 2022

The World Economic Forum (WEF) identified 12 Pillars of competitiveness which include among others: Institutions, Infrastructure, Macroeconomic Stability, Health and Primary Education, Higher Education and Training. For higher education and training, the Philippines ranked 60 out of 134 and scored 4.1 - the need for quality higher education is crucial for economies that want to move up the value chain.

The changing global market mindset continues to challenge the existing educational system and resolving the issue requires multi-sectoral cooperation.

\section{Defining the skills gap issue}

According to the Philippine Statistics Authority, Annual Labor and Employment Estimates for 2017 and 2018, 21 percent of the unemployed Filipinos are college graduates. Data shows that earning a degree does not translate to work-readiness right away. This means that graduates who are entering the workforce may not be equipped with the skills needed by the industry. There must be a system that aligns what the schools are teaching students with the skills and qualities employers look for in the applicants. Philippine 
Business for Education (PBEd), said that workforce development is an interconnected set of solutions that aligns education and training to national competitive needs. It is an approach that brings together multiple sectors to ensure that the workforce is equipped with skills relevant to the economy.

Addressing the skills gap by the academe alone is inherently difficult because there is no one-to-one correspondence between courses/programs and jobs. A software specialist for example can be directly involved in marketing, management, and production design as well. The indicators are not specific enough. Lack of skills and competencies is only one reason for unemployment. But there are people who are more educated and so are choosy about jobs and can afford to wait a longer for better jobs. There is also the so called "hard-to-fill" jobs which the academe cannot understand why this is so. Using growth sector as reference in program offerings is too blunt as well because if tourism industry for example is a growth area, the school should know what specific skills do students need to excel in this area. Another issue is the skills production lag. Training requires time and resources. With the technological advancements and globalization in today's modern society, plus the $4^{\text {th }}$ industrial revolution coming in, students today will be employed in jobs that do not exist yet. By the time the students graduate, half of what they learn are already obsolete. How much time and resources does it take to produce the needed competencies and who has the best incentive to pay for the training are issues to be addressed collaboratively by multiple sectors.

\section{Triple Helix as a Strategy}

In a knowledge-based society, academe, industry, and government have equal roles in stimulating innovation. A stable regulatory framework is important but not sufficient condition. The transformation of a university from a teaching to a research then to an entrepreneurial institution is vital. Government must help to support the new developments through changes in the regulatory environment, tax incentives and provision of public venture capital. Industry takes the role of the university in developing training and research. If knowledge-based industries are lacking, university-government interactions can help jump-start their creation; if they are present, they can help expand their growth. 
Triple helix is about the dynamics arising from the interactions between the three principal institutional spheres in an economy - academe, industry and government. The leading role of the academe in this relationship is to ensure that the knowledge it produces is useful enough to be widely shared and applied, ultimately translating into community and national development. Industry would be keen not only in knowledge application, but also in knowledge production and knowledge sharing as the way forward in the course of wealth creation. The role of governments would involve the task of facilitating universityindustry interactions by setting out appropriate policy frameworks for defining, among other things, research and development priorities in the light of prevailing socio-economic circumstances and for allocating resources across these priorities (Saad and Zawdie, 2011).

Collaboration between academe and industry has been advocated for the past year as an offshoot of one of the reports of the Congressional Commission on Education (EDCOM). According to the report, higher education is characterized by: a) large enrolment; $b$ ) imbalanced distribution; c) under investment and poor quality; d) a mismatch between programs and graduates, and between employment and society needs; and e) limited and underdeveloped graduate education.

The Commission on Higher Education (CHED) has taken measures to address the issue of quality and relevance of education offered by higher education institutions. These initiatives indirectly involve industry linkage which is one of the criteria being encouraged and monitored by CHED in its schools. Likewise, CHED, in its memorandum order of 2011 clearly stated that Higher Education Institutions (HEIs) should come up with their creative academe-industry linkage plan appropriate to the degree program and/or general education (GE) component (CMO, Series of 2011). Completing the linkage plan should be the participation of the government as an enabler through conducive policy environment and provision of rewards/incentives. Recognizing the importance of industry-academegovernment collaboration, the current Philippine Development Plan (PDP) draws clear linkages between the government strategy in enhancing the quality of education to be more responsive to industry needs and private sector involvement in developing curriculum in pursuit of leading-edge, commercial-ready innovations. The PDP also states that the government devises performance measures, incentives, and rewards for universities who collaborate with the industry. 
The university/academe-industry collaboration has slowly become the byword in the academic world to make graduates aware of the real situation and direct their interest in assisting the industry in improving products and services (Tansinsin, 2005). Both parties gain benefits from the partnership and may help improve each other's performance in their respective fields of discipline. CHED decided to focus on academe-industry linkage as one of its major areas based upon the mandate to support the academic institutions in their research efforts. While the Philippine economy requires highly skilled knowledge workers, the role of institutions in producing competent graduates has become more serious, thus, the need to establish a strong linkage between the industries and the institutions has been emphasized. Furthermore Villegas (2009) mentioned that in the tertiary level, one of the ways to improve the effectiveness of the educational process is to strike a closer symbiotic relationship between academe and industry.

Operationalizing the triple helix model of innovation in the Philippines, Philippine Business for Education (PBEd) cited existing models of workforce development showing how different sectors of society can work together to ensure that students are equipped with skills needed to secure jobs and eventually contribute to their communities (Del Rosario, 2019). PBEd is a non-profit organization and the business community's response to the need for sustained and strategic education reform in the Philippines.

In Cagayan de Oro City for example, the Cagayan de Oro Hotel and Restaurant Association (COHARA) forged a strong partnership with schools rationalizing the deployment of interns to various COHARA-member companies based on available positions. They developed an industry certification on top of the students' school diplomas which they could use to land jobs.

The "Turo-turismo" model in Bohol, on the other hand, is a perfect example of industry-academe-government collaboration. In this model, the provincial government brings together the hotels in Panglao for a Senior High School linkage program that provides work immersion opportunity for the K to 12 students. The government put up a shared training facility that offers an industry-driven curriculum developed by schools. The training facility is equipped with state-of-the-art equipment and furniture donated by partner hotels and resorts. 
PBEd for its part, is complementing Youth Works PH with United States Agency for International Development. Youth Works $\mathrm{PH}$ is a five-year private sector-led project that provides work-based training for out-of-school youth. This is a collaboration between the academe, industry, and government. TESDA prepares the training plan and provide funding through scholarship. The school delivers the training, the local government provides trainees, while the company or private sector accommodates the trainees for inplant training. Forty percent $(40 \%)$ of the training time is spent in school while sixty percent (60) is in plant training. After completion of the training, graduates are assured of employment by the Department of Labor and Employment (DOLE) through the local Public Employment Service Office (PESO).

The Philippine Chamber of Commerce and Industry (PCCI), an organization that has pioneered key legislation and policies in support of greater economic development and investment generation is now involved in education reform programs. Its active involvement in TESDA Board, National Competitiveness Council, and now the Presidential Task Force on education, PCCI is able to strengthen the presence of the private sector in crafting a cohesive policy agenda that speak of better industry-academe-government collaboration in reforming the education system, primarily by promoting human resource development in line with the demand for global competitiveness (Keh, 2018).

Various initiatives have been done by the Philippine government to promote academeindustry collaboration. In 2016, the First Calabarzon Academe-Industry Linkages Summit was held at Dela Salle University-Dasmariñas, Dasmariñas, Cavite with 296 participants from the academe, industry, and government. With the theme "Strengthening AcademeIndustry Linkage towards Calabarzon's Sustainable Development and ASEAN Economic Integration", the Summit came up with policy recommendations in the form of a Manifesto to address the job-skills mismatch and other potential issues related to ASEAN integration. The Summit was able to share the present industry skills and human resource requirements, current academic offerings and government support as well as academe-industry linkages experiences.

Dr. Adoracion Navarro, NEDA Deputy Director-General, emphasized in her keynote address the important role of closer and sustained academe industry partnerships and enabling government framework to improve the country's economic competitiveness and 
human capital amidst changing development contexts such as the ASEAN integration (Cajarte, 2016).

Another forum was organized in collaboration with the Philippine Chamber of Commerce and Industry (PCCI) Education Committee and the Export Development Council-Networking Committee on Human Resource Development on August 14, 2017 (Mirasol, 2017). Strengthening Industry - Government-Academe Linkage towards Sustainable and Innovative Growth (SIGASIG) was the theme for the 7th National Education Forum. TESDA Director General Guiling Mamondiong said that it was high time for the industry, government and academe to collaborate and work together as growth and economic accelerators in the country. He noted that by working together and in harmony, the country will be able to achieve global competitiveness. He said that TESDA will endeavor on Technical-Vocational Education and Training (TVET) for global competitiveness. He added that his agency is closely collaborating with the various industries to develop and promulgate skills they required.

An equally relevant article was written by Apipa P. Bagumbaran and published at Philippine Information Agency, Cagayan de Oro City last May 17, 2018, where she said that -strong collaboration among government agencies, the academe, and industry stakeholders is a crucial factor to put regional industries in a better position to face the challenges in both domestic and export markets.

Bagumbaran also mentioned the inputs of Dr. Rafaelita Aldaba, Department of Trade and Industry(DTI) Assistant Secretary for Industry and Development, regarding the main recommendation from the different regional consultations conducted by DTI which was the building of connected, creative, and innovative communities highlighted by more research and development (R\&D) collaboration; strong support of legislation in terms of policies that would strengthen R\&D; integration of innovation and entrepreneurship in the education curriculum; and improving the quality and utilization of government's shared infrastructure such as shared service facilities, Fablabs, and food innovation centers.

According to Asec. Aldaba, studies conducted by the Philippine Institute for Development Studies (PIDS) and the Science, Technology, Research and Innovation for Development (STRIDE) have shown that there is a weak linkage between industry and academe in terms of innovation due to widespread mistrust between the university and 
industry communities. She also added that competition is happening instead of collaboration and there is lack of research culture in universities. These findings, she said, somehow support the low ranking of the country in terms of innovation efforts. The Philippines ranked 73rd in the Global Innovation Index 2017, scoring lowest in creative outputs, human capital, and market sophistication.

While the private sector is seen as a major driver of growth, the government also plays an important role particularly on the crafting and implementation of policies that will support the growth of regional industries. Aldaba said that improved business and policy environment can attract more investments which are going to be the source of jobs, emerging new tech industries, as well as new products and services leading to improved productivity and competitiveness.

Close coordination among government agencies is also critical. Aldaba said collaboration and closer coordination within government can be promoted by expanding DOST-DTI innovation memorandum of understanding to include the Department of Information and Communications Technology which has a mandate over physical innovation infrastructure; the Department of Agriculture because of the R\&D support it provides to the agricultural sector; the Technical Education and Skills Development Authority and the Commission on Higher Education to grant more market-oriented research, commercialization support, and reforms in the curricula; the National Economic and Development Authority for the monitoring of innovation policy and evaluate implementation; the Department of Finance for fiscal support; and the Department of Interior and Local Government to link up with local government units. (APB/PIA-10)

\section{Theoretical Framework}

This study draws essentially on the theory of social capital which contends that social relationships are resources that can lead to the development and accumulation of human capital (Machalek and Martin, 2015). It also argues for greater inter-organizational relationships to continuously acquire and update external knowledge and exploit it for sustainable competitive advantage. This is clearly demonstrated in the Triple Helix Model of innovation. 
The triple helix model was proposed by Etzkowitz and Leidesdorff in mid 1990s to study the University, Industry, and Government collaboration at local and regional level. There are three kinds of triple helix structures studied with particular reference to organizations. In triple helix 1 , the state or government overshadows the university and industry structures. State governs over the university and industry structures. The triple helix 2 illustrates the three organizations separate and apart from each other, interacting only modestly across strong boundaries (Etzkowitz, 2003:302). This structure represents limited relations among the three actors. In triple helix 3, each institutional sphere keeps its own distinctive characteristics and at the same time also assumes the role of the others. The evolutionary process underlying the triple helix system is graphically shown below.

\section{Figure 1.}

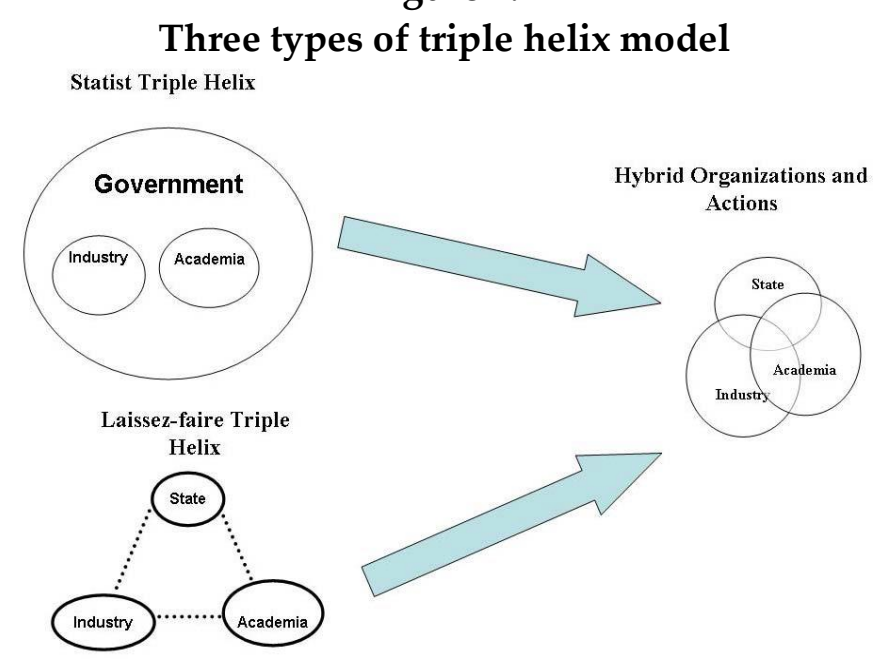

Source: Derived from Etzkowitz (2008)

This study is also anchored on the collaborative governance theory by Ansell and Gash (2007). Collaborative governance is defined as the process of establishing, steering, facilitating, operating, and monitoring cross-sectoral organizational arrangements to address public policy problems that cannot be easily addressed by a single organization or the public sector alone. These arrangements are characterized by joint efforts, reciprocal expectations, and voluntary participation among formally autonomous entities, from two or more sectors - public, for profit, and non-profits in order to leverage the unique attributes and resources of each. While education is vital for human capital development, and that equal access to higher education, job-skills mismatch, and delivery of quality education remain to be pressing concerns among parents, government, industry and policy makers, collaboration 
among the academe, industry, and government is of utmost importance, hence, the subject of this study.

Figure 2.

Human Capital Development (HCD) Framework showing the interplay between the academe, industry, and government (triple helix model of innovation)

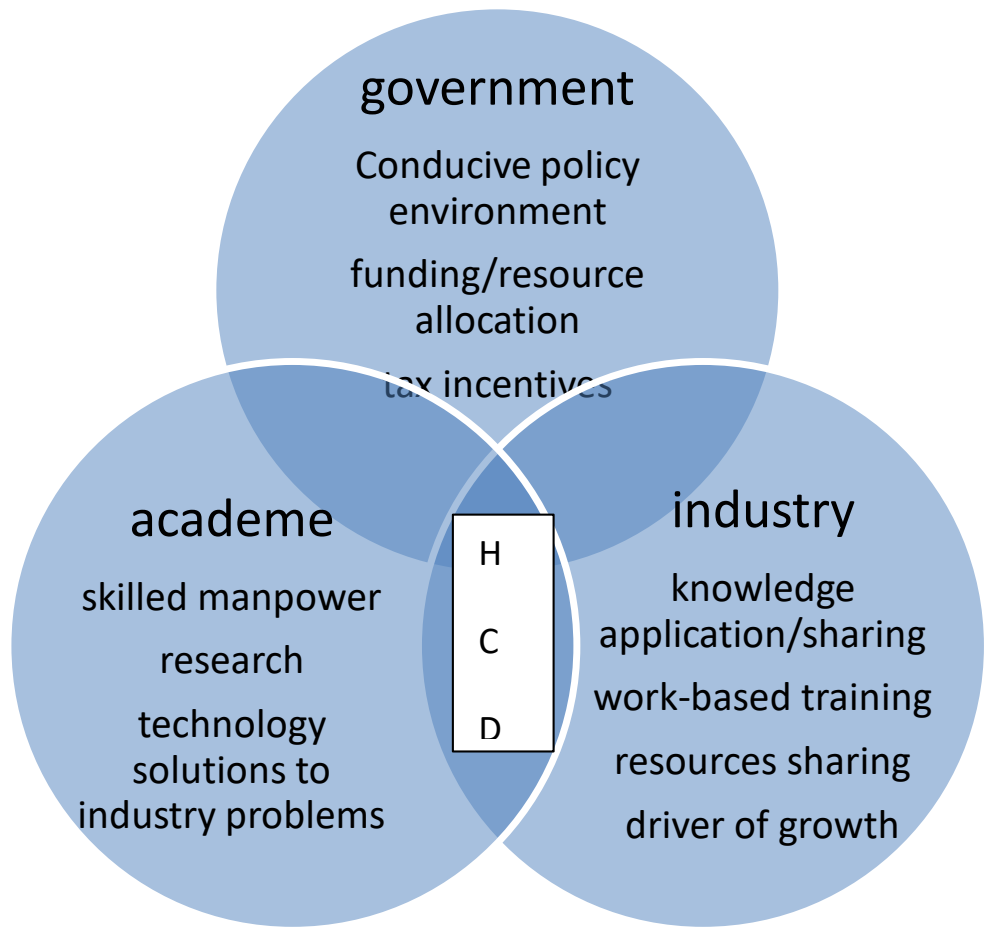

Source: Obtained from the primary data of the study

Finally, the study is inspired by Asset-Based Community Development (ABCD) model developed by John McKnight and John Kretzmann. Asset Based Community Development $(\mathrm{ABCD})$ is an approach to sustainable community-driven development. Beyond the mobilization of a particular community, it is concerned with how to link micro-assets to the macro-environment. Asset Based Community Development's premise is that communities can drive the development process themselves by identifying and mobilizing existing, but often unrecognized assets, thereby responding to challenges and creating local social improvement and economic development (ABCD Toolkit). ABCD approach is illustrated below. 
Figure 3.

Asset-Based Community Development Methodology

Asset-based Community

Development Methodology

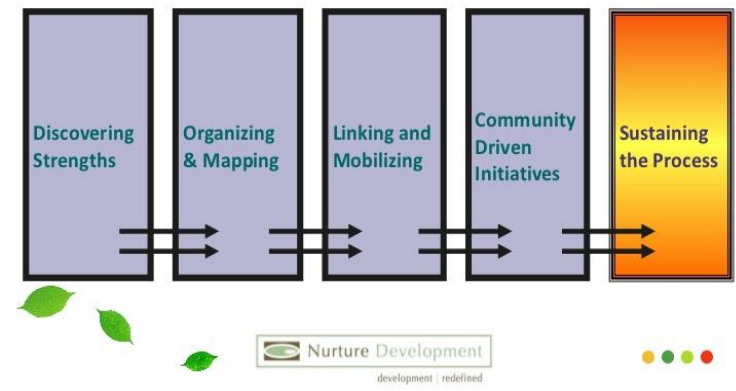

Source: Nurture Development

The researcher believes that development should start from the community. Hence, creation of Local Colleges and Universities (LCUs) is an example of asset-based community development. Giving the poor people in the community access to higher education ensures productive citizens, inclusive growth, sustainable development and vibrant community.

\section{Methodology}

In addressing the issues, desk study and Key Informants' Interview were employed. The desk study involves significant readings and analysis of theories relating to triple helix model of innovation or academe-industry-government collaboration. Review of documents such as school records and government documents pertaining to LCUs was used. Articles and reports about the Global Competitiveness, Philippine Higher Education condition, employment and unemployment situation in the Philippines, and insights from the private sector on how to connect education to the industry for human capital development were instrumental in providing a broader picture of the study. Interviews with the respondentLCUs and the industry represented by the Philippine Business for Education (PBEd) were conducted to gather primary data on partnership initiatives aimed at developing human capital. The respondents from subject LCUs were selected based on their authority and knowledge of the topic under study. The respondents were Vice Presidents of LCUs, Planning Officers, Head of Research Department and Head of Linkage and External Affairs. The interview was conducted using a semi-structured questionnaire prepared in such a 
manner that the informants can speak freely on the topic and can elaborate more if the researcher needs further substantiation.

A qualitative case study approach was adopted to investigate the data on each LCU experiences. This approach is well suited to the type of data obtained through semistructured interviews and secondary sources. With a qualitative research approach, information that is not previously expected can be gathered. Thus, the resulting data is likely to be richer, more descriptive, and accurate according to the perspectives of the respondents chosen.

\section{Results and Discussion}

Local Colleges and Universities (LCUs) are local government-initiated tertiary schools in the Philippines. Institutionalized after the passage of the 1991 Local Government Code, LCUs are distinct from the other public higher education institutions (HEIs) of the country like State Universities and Colleges (SUCs) whose budgetary allocation is determined by the national congress and the central government.

LCUs contributed greatly to governance, higher education and public policy. Dayrit (2005), in his study, argued that it is the only hope for underprivileged children of poor Filipino families for acquiring a college education. Chao (2012) mentioned that LCUs address the higher educational gaps at the local level, while Pernia (2014) noted that LCUs are investment in human development and social services provision. Montemar, Recio, Hecita and dela Cruz (2013) consider LCUs as local government units' poverty alleviation intervention and a mechanism to control crime.

This study presents three (3) LCUs in Metro Manila initially to serve as benchmark of other LCUs particularly those in the provinces. It showcases the various partnership initiatives with industry and government primarily for the purpose of addressing the issues and constraints confronting higher education institutions like LCUs, with the end in mind of producing better quality graduates who can contribute to economic development. It highlights the benefits and impact of existing linkage programs and the low hanging fruits they see and reap out of collaboration. However, the paper does not delve on investigating the actual number of graduates of each respondent-LCU who became successful and have impacted the community. Rather, it presents the existing partnership modalities, benefits 
and accomplishments, issues and challenges encountered. The respondent-LCUs are: University of Makati, Taguig City University, and Pamantasan ng Lungsod ng Muntinlupa. These schools are recommended by the Association of Local Colleges and Universities Committee on Accreditation (ALCUCOA) as respondents of this study because they have programs subjected for accreditation. ALCUCOA is the certified accrediting body for LCUs.

\section{University of Makati Strategies}

The University of Makati (UMak), is a public locally funded university of the local government of Makati located at JP Rizal Extension, West Rembo, Makati City. Currently having a total student population of 15,000, UMak has consistently redefined educational excellence as it fulfilled seriously its mandate of addressing the needs of the less privileged citizens of Makati City and its sister cities and municipalities. However, the challenge of having $100 \%$ employability of its graduates three months after graduation remains a challenge for years. For this reason, UMak has ventured into various innovative education strategies to address the challenge of employability due to job-skills mismatch. Bringing the industry into the academe is one best strategy. UMak pioneered the implementation of the Dualized University Education System in the Philippines and entered into joint venture agreement in establishing the following colleges: College of Allied and Health Studies in partnership with STI -Philippine Health Educators Inc., College of Maritime Leadership Innovation in partnership with Southfield Agencies, and School of Continuing Professional Education (SCOPE) now renamed as Center for Continuing, Advanced and Professional Studies.

\section{The Dualized University Education System: Bringing the Industry into the Academe}

The University of Makati is the first university in Asia to introduce and design a system termed “Dualized University Education System" (DUES) model of course design. The DUES is an innovative program anchored on a dynamic joint venture involving the academe and the industry to ensure a career-focused education. The concept "dual" means learning takes place in two venues, school and industry while "system" calls for the interphase of the instructing parties, the academe and industry, supplementing and 
coordinating one another in their efforts to prepare and educate students. The Concept of DUES is illustrated below:

Figure 4.

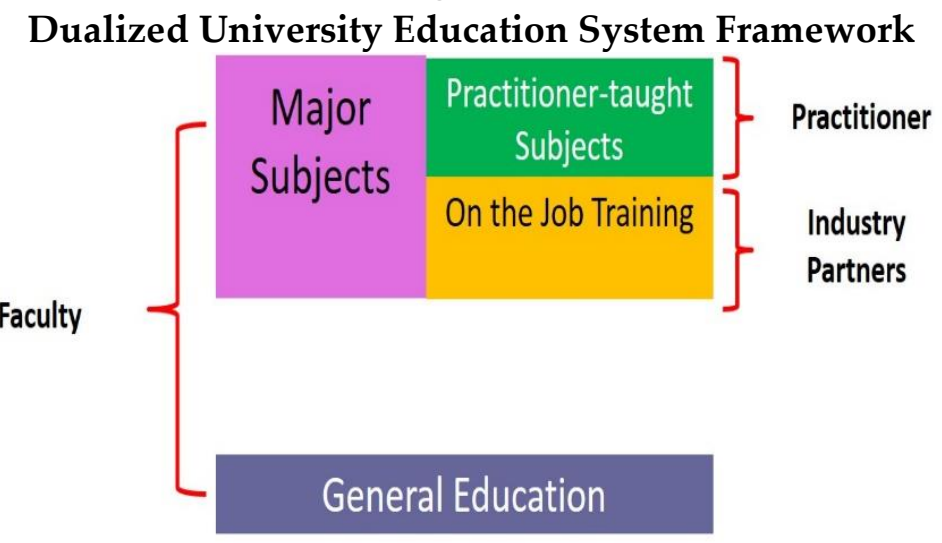

Source: Umak Student Handbook

The University of Makati emphasizes quality education without losing sight of the basic principle that the University's major markets of students are the children of Makati City's underprivileged citizens. The DUES sets into motion an enrolment to employment system because courses are aligned with the work-force competency needs of the City of Makati and nearby cities.

Implemented in 1999 DUES program was introduced in the following Colleges: a). College of Business Administration for BSBA Major in Building and Property Management; BSBA Major in Supply Chain Management; and b) College of Technology Management for BS in Building Technology Management; BS in Electrical Technology; BS in Electronics and Telecommunications Technology; and Industrial Facilities Technology.

\section{UMak-College of Allied and Health Studies (COAHS)}

UMak entered into a joint venture with STI to run the College of Allied and Health Studies offering medical allied courses such as Nursing, Radiologic Technician, Pharmacy, and Masters in Nursing. Like the DUES concept, the general education subjects are taught by UMak faculty while the professional subjects are delivered by industry partners with UMak as the degree-granting institution. On the administrative side, STI pays rental for the spaces occupied in UMak. The partnership is immediately profitable contributing over P100 million in dividends, P40 million in rentals and faculty fees and over P100 million in 
scholarships for deserving Makati residents. Over the years, the COAHS has performed well in the licensure exams for Nursing and Rad Tech by producing topnotchers.

\section{UMak-College of Maritime Leadership Innovation (CMLI)}

The College of Maritime Leadership Innovation which offers maritime courses was established in partnership with Southfield Agencies, a ship manning company capable of providing employment to maritime graduates. Said company is not into training the reason why it partnered with UMak to offer the maritime courses. Southfield refurbished a portion of the $4^{\text {th }}$ floor of the administration building for its simulated classrooms and laboratory. Equipment used for teaching and learning were brought in UMak. Like the other joint ventures, the general education subjects are taught by UMak faculty while the professional subjects are delivered by the industry partners. UMak is the degree-granting institution. Both parties have joint stake in the selection of students. After the expiration of the agreement, the equipment and properties of the industry partner belong to the partner and can be pulled out from the university but the same can be donated to UMak. CMLI offers ladderized degree programs in: Diploma in Marine Transportation leading to a Bachelor's Degree in Marine Transportation and Diploma in Marine Engineering leading to a Bachelor's Degree in Marine Engineering. The special features of the programs are: free tuition scholarship (if grades are maintained); study-now-pay-later scheme for miscellaneous fees; guaranteed shipboard training; guaranteed employment in Southfield's fleet of vessels. The students are in UMak for the first 3 years while on shipboard training on its $4^{\text {th }}$ year. Currently, the college has 185 students on shipboard training who are earning more or less $\$ 350$ a month, while 144 students are on-campus.

Figure 5.

CMLI Career Path

\section{STUDENT -TO-SENIOR OFFICER} PATH

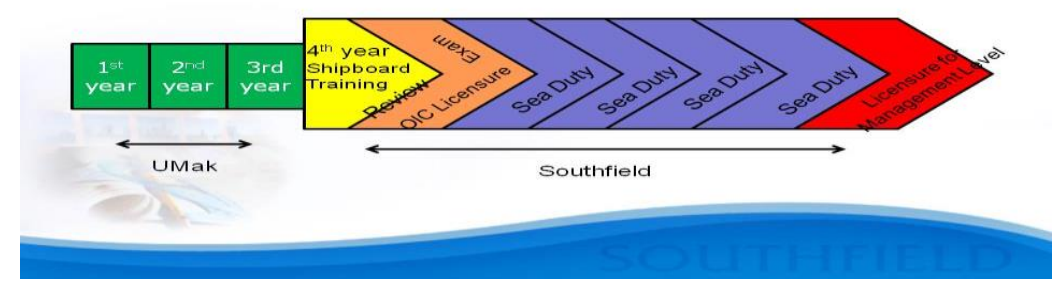

Source: College of Maritime Leadership Innovation 
UMak-College of Continuing, Advanced, and Professional Studies (CCAPS) (formerly School for Continuing Professional Education -SCOPE)

The College of Continuing, Advanced, and Professional Studies (formerly SCOPE) was primarily established to address the needs of employees who are already expert on what they do but do not have the credentials or degree required for the position. An equivalency program is offered, taking into consideration the students' work experience and trainings acquired. UMak partners with companies or institutions where potential students are employed to ensure captive market. Evaluation of students' credentials to pre-qualify them in the program is easy because they come from the same company where most trainings/seminars conducted to employees are mostly similar. An example of this is the BS in Micro Finance for the employees of ASA Philippines, a financing company. Another program offered is the Executive Bachelors of Arts in Political Science major in Local Government Administration and Masters in Development Management and Governance specially designed for local government officials. The Philippine Councilors League is among the participants of the program. Special features of the program are: grant of equivalent academic credits to participant's career experience and achievements; individually customized study programs integrating subject matter relevant to student's work context, and assessment based on terminal papers and development strategies for their specific functions and positions.

\section{UMak and PBEd Partnership}

The Philippine Business for Education (PBEd) has partnered with UMak to help implement YouthWorks PH, a five-year, nationwide initiative in partnership with United States Agency for International Development (USAID) which provides work-based training for Filipino youth not in education, employment and training (NEET). The project engages the industry, academe, government and other education and employment stakeholders in improving human capital development in the Philippines. Under the agreement, PBEd provides technical support to UMak in developing the work-based training design on Masonry and Tile-setting; conducts relevant workshops or training to UMak faculty (from the College of Construction Sciences and Engineering) who will deliver the in-school training; allows industry immersion of UMak trainers to EEI, partner company identified by 
PBEd; and issues license or certification to UMak trainers through the Education Development Center, Inc. The intended youth-participants under this project are Makati out-of-school youth who will be chosen with the help of the local government. TESDA will provide scholarship funding to the trainees. According to one of the UMak trainers, the training has not started yet because of the difficulty in recruiting participants. This might be due to the training programs (masonry and tile-setting) which are not attractive to Makati out-of-school youths considering that Makati is a business center and business courses can be one of their preferences.

\section{Taguig City University (TCU): A Caring University}

Taguig City University is formerly Pamantasan ng Taguig established through Ordinance No. 29, Series of 2004. It was renamed Taguig City University by virtue of City Ordinance No. 13, Series of 2009. Located at General Santos Avenue, Central Bicutan, Taguig City, TCU is catering to 8,228 students with 249 faculty. TCU is working closely with the city government of Taguig as its programs are anchored on the 10-Point Agenda of the City Mayor, Hon. Lino Cayetano to wit: Safe City, Good Governance, Healthy City, Caring Community, Inclusive Quality Education, Green Governance, Responsive, Relevant and Resilient Infrastructure, Economic Dynamism, People's Participation, and Youth Agenda.

TCU has 316 industry partners generally for internship. According to the VP for Research, the presence of the Department of Science and Technology (DOST) in the area is quite favorable for TCU since it serves as laboratory for the students which is made possible by taking in some of its employees as part-time faculty. Generally, TCU's linkage involvement with industry are on internships, curriculum design, and resources sharing. TCU is fortunate to be chosen by IBM to implement the P-Tech project - a perfect example of triple helix model of innovation.

IBM partnered with TCU to introduce a new educational platform and opportunity to address new collar skills shortage. The six-year partnership involves embedding the socalled P-Tech (Pathways in Technology Early College High School) school model in the university's curriculum starting with senior high students. Philippines is the second country in Southeast Asia to implement P-Tech and TCU is the pilot university for the said program in the Philippines. According to the Dean of the IT department of TCU, P-Tech will be 
implemented in Grades 11 and 12 of the Senior High School and the other 2 years in college where the students will be graduating with the degree in Associate in Computer Technology. The City Government of Taguig provides the laboratory while IBM provides the technology. Asia Pacific College was tapped to train TCU faculty who will implement the program designed by IBM. Students under the program will participate in paid internships that provide real workplace experiences. These opportunities will equip students with the necessary technology and workplace skills, as well as the degrees for competitive and fulfilling "new collar" careers. P-Tech creates a direct path between high school, college and career by uniting the expertise of the public and private sectors to strengthen education and reinvigorate local economies.

\section{Pamantasan ng Lungsod ng Muntinlupa (PLMun)}

The third LCU in the study is the Pamantasan ng Lugsod ng Muntinlupa located at Poblacion, Munitinlupa City. Formerly Muntinlupa Polytechnic College, it was converted to Pamantasan ng Lungsod ng Muntinlupa by virtue of City Ordinance No. 03-089 in March, 2003. PLMun is strongly supported by the local government of Muntinlupa in the form of educational assistance and other incentives to students. This is on top of the tuition-free tertiary education of all students under the Unified Student Financial Assistance System for Tertiary education (UniFAST) given by the national government. PLMun's partnership modalities with the private sector include: internship for students, scholarship grants, donation of instructional materials/equipment like computer units donated by Sykes Asia, and seminars and trainings for students and faculty. Among its scholarship benefactors are Puregold, Green Cross, Charity First, Lingap Adhikain Foundation, and Howgood Foundation. Financial assistance are given to scholars. Presently, Accenture is conducting an English Proficiency Intervention program to ten (10) faculty members who are assigned to teach the ten (10) Chinese students who are coming to PLMun for its student exchange program. Another program being done by Accenture is the Edulink. It is a 15-day training workshop for near hires. According to the head of the Office of Linkages and external Affairs, PLMun is willing to benchmark with other universities to explore on other partnership modalities such as curriculum design and intervention.

While UMak has innovative programs that are uniquely designed to fit industry needs, CHED recognition and certification remains a serious challenge because CHED has no 
training regulations and standards to assess said programs that are uniquely UMak. However, true to its mission of providing employable skills to students, UMak continuously innovate and made a difference in the Philippine educational landscape.

The other LCUs are relatively young when it comes to linkage programs as they are just starting to venture into other partnership modalities. Continuous search for industry partners and venturing into other partnership modalities beyond on-the-job training must be done.

\section{Concluding Remarks}

This study started with three objectives: 1) to know the linkage/partnership initiatives of the identified LCUs with industry and government; 2) how this collaboration addresses the constraints and issues of the LCUs in developing human capital which means producing better quality graduates; and 3) to draw policy recommendations for the institutionalization of academe-industry-government collaboration anchored on the triple helix model of innovation.

Much has been said about academe-industry-government collaboration. Various partnership modalities were cited including several government and private sector-led program initiatives on human capital development pointing out that developing a country's human capital cannot be done by the academic sector alone but interrelation with industry and government brings them all together. Connecting industry and academe, facilitating linkages and providing an enabling environment to sustain such partnerships are tasks that should be done by local governments and state agencies.

From the data presented, the partnership modalities common to the three (3) LCUs under study are: student internship, scholarship, faculty training, and physical resources provision. Market-driven curricular programs (DUES) jointly designed by the school and its partners were done in University of Makati only, though, Taguig City University is piloting the P-Tech project of IBM which involves embedding of the program to the curriculum. These innovations including those mentioned by the Philippine Business for Education (PBEd) like Turo -Turismo and COHARA among others, are best practices which other local government units and LCUs particularly those in the provinces could look into. While the DUES strategy of UMak ensures high employability rate of graduates, program recognition 
from the Commission on Higher Education (CHED) remains a challenge. Compensating the industry practitioners teaching the major subjects without Masters Degree was once a problem as well. However, with the global economy and $4^{\text {th }}$ industrial revolution upon us, schools must get out of their silos and be sensitive to the pulse of industry particularly in developing curricula that address the needs of the community. Therefore, the following suggestions are made for policy consideration:

1. To promote triple helix model of innovation in human capital development programs

2. CHED should give local industry-academe partnerships more flexibility to design courses relevant to their communities

3. Local government units should give incentives to companies collaborating with universities. It can be discount on tax or Mayor's permit.

4. CHED should issue a memorandum ensuring industry practitioners involvement in curriculum development

5. The government through DOLE should provide the schools and other training institutions timely and usable labor market data

6. Local government units without existing locally-funded schools such as LCUs may consider establishing one. Capacitating these LCUs through the triple helix model would capture the interest of the youth to stay and study in their localities instead of migrating to urban areas, thereby addressing rural poverty, problem on human settlement in urban areas, promoting inclusive growth and sustainable development.

\section{References}

Ansell, Chris and Alison Gash. (2007). "Collaborative Governance in Theory and Practice". Journal of Public Administration Research and Theory. Vol 18. Pgs 543-571.

Asian Development Outlook 2018: How Technology Affects Jobs. Retrieved from adb.org/publication/Asian-development-outlook-2018-how-technology-affects-jobs

Bagumbaran, Apipa P. (2018). “Collaborative Innovation: Key to Industry Development. Philippine Information Agency. https://pia.gov.ph/news/articles/1008318 
Bernarte, Racidon P. (2014). “Academe-Industry Partnership in the Philippines: Nature, Benefits and Problems". Asia Pacific Higher Education Research Journal. https://www.academia.edu/9402907/Acadme_Industry_Partnership_in_the Philippines_Nature_Benefits_Problems

Cajarte, Theresa Jane (2016). “Industry, Academe and Government Forge Stronger Partnerships to Solve Job-Skills Mismatch. First Calabarzon Academe-Industry Linkages Summit. http://calabarzon.neda.gov.ph/2016/10/27/industry-academe-andgovernment-forge-stronger-partnerships-to-solve-job-skills-mismatch/

Chao, Roger Jr. (2012). “Democracy, Decentralization, and Higher Education: The Philippine Case. Asia Pacific Social Science Review, 12(1), 31-44.

Commission on Higher Education Memorandum Order (2006), 32 Series Art. VII

Commission on Higher Education Memorandum Order (2011), 10 Series No. 1.

Commission on Higher Education Memorandum Order (1996), 48 Series No. 2.

Danao, Dr. Carolina P. (2005-02-20). "The medium-term higher education development plan and the local colleges and universities". Manila Bulletin. Archived from the originalon 2008-10-03.

Dayrit, N. M. (2005). The local government units'e venture into the Philippine education system: The establishment of local colleges and universities. In Workshop on Enlarging Citizen Participation and Increasing Local Autonomy in Achieving Social Harmony Workshop, Network of Asia Pacific Schools and Institutes of Public Administration and Governance (NAPSIPAG) Annual Conference.

Del Rosario, Ramon Jr. (2019). “Linking Industry and Academe". Retrieved from @inquirerdotnet. Philippine Daily Inquirer. February 23, 2019

Etzkowitz, Henry, Dzisah, James, Ranga, Marina and Zhou, Chunyan (2007). “The Triple Helix

ModelofInnovation".https://pdfs.semanticscholar.org/4bcc/884ed691ff919ae18c974e15b 6baeba08e7f.pdf

Congressional Commission on Education Report. Retrieved from scribd.com/document/269280174/edcom-report 
Global Competitiveness Report 2017. Retrieved from weforum.org./reports/globalcompetitveness-report-2017

Global Competitiveness Report 2019/World Economic Forum. Retrieved from weforum.org/reports/global-competitiveness-report-2019

JobsFit 2022 Labor Market Information Regional Reports. Retrieved from ble.dole.gov.ph/

Jobstreet.com Fresh Graduate Report 2018

Keh, Antonio (2008). "Addressing Employment and Skills Mismatch for Gainful Employment: Mainstreaming Public-Private Partnership". $8^{\text {th }}$ National TVET Forum. December 11-12, 2008. Retrieved from www.tesda.gov.ph>uploads $>$ tvet - forum

Machalek, Richard and Martin, Michael (2015). "Sociobiology and Sociology: A New Synthesis".

International Encyclopedia of the Social \& Behavioral Sciences (Second Edition). Sciencedirect.com/topics/social-sciences/social-capital-theory.

Macha, Wilson, Mackie, Christopher and Magaziner, Jessica (2018). "Education in the Philippines". World Education News and Reviews. wenr..wes.org/2018/03 Educationin-the-philippines

McKnight, John and John Kretzmann. “Asset-Based Community Development). Nurture development.org/abcd-institute/

Mgonja, Christopher (2017). “Enhancing the University-Industry Collaboration in Developing Countries through Best Practices". International Journal of Engineering $\begin{array}{llllll}\text { and } & \text { Technology-Volume } & 50 & \text { No. } & 4 & \text { August }\end{array}$ Researchgate.net/publication/321203615

Mirasol, Grace T. (2017)." National Education Forum strengthens Industry-Academe Ties". Export Development Council. http://www.edc.net.ph/national-education-forumstrengthens-industry-academe-government-ties/

Pamantasan ng Lungsod ng Muntinlupa Brochure Pernia, Ronald (2014). "The LGUs Venture into Tertiary Education: The Case of Sibonga Community College". (Unpublished Masters Thesis). University of the Philippines Cebu. 
Pernia, Ronald (2017). “Exploring Educational Politics in Two Local Colleges in Cebu Province, Philippines". Asia Pacific Journal of Multidisciplinary Research, Vol. 5, No. 3, August 2017

Philippine Development Plan 2017-2022. Retrieved from neda.gov.ph/wp-content/uploads/ 2018/01/Abridged-PDP-2017-2022

Philippine Statistics Authority - Labor Force Survey. Retrieved from https://psa.gov.ph Philippine Business for Education publication (2015). "Costing and Financing Philippine Higher Education" culled from the study of Tullao, Tereso; Cabuay, Christopher James; Garcia, Emmanuel; Ang, Dustin Timothy \& Sayoc, Rosanina (December, 2014)

Razak, Abd, (2015). “The Triple Helix Model for Innovation: A Holistic Exploration of Barriers and Enablers". http://eprints.uwe.ac.uk

Saad, Mohammed and Zawdie, Girma (2011). "Theory and Practice of the Triple Helix System in Developing Countries: Issues and Challenges". crcpress.com ISBN 9780415475167 - CAT\# RU56308. Routledge

Taguig University picked as PH pilot site for IBM's tech education model. Retrieved from newsbytes.ph/taguig-university-picked-as-ph-pilot-site-for-ibms-tech-educationmodel/

Tansinsin, L.G. (2005). “Development of University-Industry Partnerships for the Promotion of Innovation and Transfer of Technology: Philippines

UNESCO Graduate Employability Report in Asia. Retrieved from apyouthnet.ilo.org/resources/Graduate-employability-in-asia.

University of Makati Accomplishment Reports

Villegas, M. (2009). “Symbiosis between Academe and Industry”. Manila Bulletin, November 9, 2009. 